\title{
HUBUNGAN ANTARA KEBIASAAN BELAJAR DAN MOTIVASI \\ BELAJAR DENGAN PRESTASI BELAJAR MATEMATIKA SISWA SMP SELAMA PEMBELAJARAN DARING
}

\author{
Khoirotul Mahmudah ${ }^{1}$, Didik Sugeng Pambudi ${ }^{2}$, Ervin Oktavianingtyas ${ }^{2}$, Nurcholif Diah \\ Sri Lestari ${ }^{2}$, Randi Pratama Murtikusuma ${ }^{2}$ \\ Program Studi (S1)Pendidikan Matematika, FKIP, Universitas Jember \\ Jln. Kalimantan 37, Jember 68121 \\ E-mail:khoirotulmahmudah99@gmail.com
}

\begin{abstract}
The purpose of this study was to determine the correlation between study habits and learning outcomes, between motivation and learning outcomes, and habits and motivation on learning outcomes in mathematics during online learning. The sampling technique used the Slovin formula approach. Hypothesis testing using multiple regression analysis techniques, Pearson Correlation test, $F$ test, and the coefficient of determination of 5\%. Learning habits and motivation are measured by a questionnaire that is declared valid and has been tested for validity and reliability. To measure learning habits and motivation was carried out by distributing questionnaires, while for learning outcomes from the documentation of mathematics scores. The results showed that: there was a positive and significant correlation between study habits and learning outcomes; there is a positive and significant correlation between learning motivation and learning outcomes; there is a positive and significant correlation between learning habits and motivation with mathematics learning outcomes.
\end{abstract}

Keywords: Learning Habits, Learning Motivation, Mathematics Learning Outcomes, Online Learning

\section{PENDAHULUAN}

Sistem pendidikan di Indonesia mengalami perubahan dikarenakan munculnya pandemi Covid-19. Mendikbud menghimbau agar semua satuan pendidikan dibawah Kemendikbud untuk menunda penyelenggaraan acara dan menggantikannya dengan komunikasi daring. Untuk daerah yang telah terdampak Covid-19 diberlakukan pembelajaran dari rumah secara daring [1]. Pembelajaran daring merupakan pembelajaran yang menggunakan jaringan internet dengan aksesibilitas, konektivitas, fleksibilitas serta kemampuan untuk memunculkan berbagai jenis interaksi dalam pembelajaran [2].

Pendidikan adalah suatu proses atau kegiatan yang diarahkan untuk mengubah tabiat manusia [3]. Kegiatan pembelajaran dalam pendidikan berupa proses bimbingan yang dilakukan oleh pendidik kepada siswanya. pembelajaran adalah suatu proses yang memiliki tujuan, seberapa sederhanapun suatu proses pembelajaran tersebut pastinya akan diarahkan untuk mencapai tujuan tertentu [4]. Berdasarkan hal tersebut, dapat dikatakan bahwa pembelajaran merupakan kegiatan belajar mengajar dari pendidik kepada peserta didik yang memiliki tujuan tertentu.

\footnotetext{
${ }^{1}$ Mahasiswa Program Studi Pendidikan Matematika FKIP Universitas Jember

${ }^{2}$ Dosen Program Studi Pendidikan Matematika FKIP Universitas Jember
} 
Salah satu pembelajaran dalam dunia pendidikan yaitu pembelajaran matematika. Matematika adalah suatu sumber dari ilmu-ilmu yang lainnya, sehingga tidak bergantung pada ilmu lain seperti fisika, kimia, ekonomi, dan lain sebagainya. dan pada perkembangannya matematika tidak bergantung pada ilmu lain [5]. Matematika juga merupakan salah satu cabang dari ilmu dasar yang berperan penting untuk perkembangan Ilmu Pengetahuan dan Teknologi (IPTEK) [6]. Pembelajaran matematika disekolah merupakan proses penyampaian materi matematika oleh guru kepada siswanya yang bertujuan agar siswa dapat memahami materi matematika yang telah disampaikan.

Keberhasilan bimbingan dalam pembelajaran dapat dilihat salah satunya dari prestasi belajar peserta didik. Prestasi belajar adalah hasil dari penilaian oleh pendidik terhadap proses belajar dan hasil belajar peserta didik sesuai dengan tujuan instruksional mengenai isi pelajaran dan perilaku yang diharapkan dari peserta didik [7]. Beberapa faktor yang dapat mempengaruhi prestasi belajar diantaranya yaitu faktor internal dan faktor eksternal. Faktor internal terdiri dari kemampuan belajar siswa, motivasi belajar, minat dan perhatian, sikap, kebiasaan belajar, ketekunan, keadaan fisik dan kesehatan siswa; sedangkan untuk faktor eksternalnya adalah lingkungan. Lingkungan ini meliputi lingkungan keluarga, sekolah dan masyarakat [8].

Saat ini pembelajaran dilaksakan secara daring. Pembelajaran daring adalah pemanfaatan dari jaringan internet yang digunakan untuk proses pembelajaran. Pada tahun 2020, mulai diberlakukannya pembelajaran daring secara total di Negara Indonesia atau bahkan di seluruh negara, hal ini dikarenakan munculnya pandemi Covid-19 yang melanda seluruh dunia [9]. Pembelajaran daring menyebabkan peluang siswa untuk memegang perangkat keras seperti smartphone yang digunakan untuk sarana pembelajaran daring dapat digunakan siswa sebagai sarana untuk bermain game atau chatting bahkan dapat melakukan kebiasaan - kebiasaan lain yang dapat mengganggunya selama belajar yang dilaksakan secara daring [10]. Hal ini menyebabkan kebiasaan kebiasaan siswa selama belajar di masa pandemi harus lebih di perhatikan, dikarenakan kebiasaan belajar siswa menjadi salah satu faktor yang dapat mempengaruhi prestasi belajar siswa.

Kebiasaan belajar merupakan pola perilaku yang dilakukan dalam belajar yang dapat menyangkut mengenai pengetahuan, sikap dalam belajar dan keterampilan yang mempunyai pengaruh yang besar dalam kehidupan seseorang [11]. Dengan demikian kebiasaan belajar merupakan suatu kegiatan yang dilakukan secara berulang-ulang pada kegiatan belajar seseorang dikarenakan sudah menjadi rutinitasnya Kebiasaan belajar siswa dapat terlihat dari waktu yang digunakan siswa untuk belajar, kecenderungan siswa untuk belajar sendirian atau bersama orang lain, dan perilaku siswa saat mengalami kesulitan belajar.

Selain itu, pembelajaran yang dilaksanakan secara daring membuat siswa kurang bisa menunjukkan keaktifan sekaligus kreativitasnya selama kegiatan pembelajaran daring berlangsung. Pembelajaran daring yang dilaksanakan selama masa pandemi ini membuat banyak siswa tidak ikut serta secara aktif dalam pembelajaran dan kurangnya motivasi siswa selama mengikuti pembelajaran daring [12]. Berdasarkan hal tersebut, maka motivasi siswa selama mengikuti pembelajaran daring perlu dikaji lebih lanjut, dikarenakan motivasi belajar siswa menjadi salah satu faktor yang dapat mempengaruhi prestasi belajar siswa. Dengan demikian, faktor internal yang dapat mempengaruhi prestasi belajar siswa selama masa pandemi dapat terletak pada kebiasaan belajar dan motivasi belajar siswa.

Motivasi adalah keseluruhan dari daya penggerak yang ada di dalam diri siswa yang dapat menimbulkan kegiatan belajar, yang dapat menjamin terjadinya kegiatan belajar 
serta dapat memberikan arah pada kegiatan belajar, sehingga tujuan belajar yang diinginkan dapat tercapai oleh siswa [13]. Berdasarkan pendapat tersebut, dapat dikatakan bahwa motivasi adalah daya atau usaha yang mampu menggerakkan seseorang untuk dapat mencapai tujuan yang ingin dicapai. Motivasi belajar siswa dapat terlihat dari semangat siswa dalam mengikuti pembelajaran daring, semangat siswa untuk melaksanakan tugas yang diberikan selama pembelajaran daring, tanggung jawab siswa dalam mengerjakan tugas yang diberikan selama pembelajaran daring, respon siswa terhadap stimulus yang diberikan guru selama pembelajaran daring, serta rasa senang dan puas dalam mengerjakan tugas selama pembelajaran daring. Hal ini menyebabkan kurangnya keterlibatan siswa dalam belajar saat pembelajaran daring dan dapat menyebabkan penurunan prestasi belajar siswa.

Banyak penelitian yang telah dilakukan mengenai faktor - faktor yang dapat mempengaruhi prestasi belajar siswa sebagai objek dari penelitian. Salah satu hasil penelitian menunjukkan bahwa ada pengaruh positif dan signifikan antara sikap belajar dan motivasi terhadap prestasi belajar matematika siswa secara parsial dan simultan [14]. Adapula hubungan yang signifikan antara motivasi belajar dan kebiasaan belajar dengan prestasi belajar matematika siswa [15]. Ada juga hubungan antara sikap siswa dengan prestasi belajar matematika siswa [16]. Ada juga pengaruh yang signifikan dan positif antara minat belajar siswa dalam hal perasaaan senang, perhatian dan kemauan secara bersama-sama terhadap prestasi belajar siswa pada mata pelajaran matematika [17]. Adapula hubungan yang positif antara gaya belajar dan siswa dengan prestasi belajar siswa kelas XI IPA dan IPS [18]. Ada juga pengaruh antara motivasi belajar dan kebiasaan belajar secara simultan terhadap prestasi belajar ekonomi siswa kelas XI IPS [19]. Adapula pengaruh kebiasaan belajar dan motivasi belajar terhadap prestasi belajar siswa secara parsial dan simultan pada mata pelajaran seni budaya [20].

Namun, pada penelitian - penelitian tersebut dilakukan ketika pembelajaran dilaksanakan secara tatap muka atau luring, sehingga ketika pembelajaran daring diberlakukan selama masa pandemi ini, belum diketahui hubungan atau pengaruhnya terhadap prestasi belajar siswa. Berdasarkan hal tersebut maka perlu dilakukan penelitian mengenai faktor - faktor yang berhubungan atau mempengaruhi prestasi belajar siswa khususnya dalam faktor kebiasaan belajar dan motivasi belajar selama pembelajaran daring, sebab indikator - indikator kebiasaan belajar dan motivasi belajar selama pembelajaran daring tentunya berbeda dengan pembelajaran luring. Peneliti memilih faktor yang dapat mempengaruhi prestasi belajar siswa yang berasal dari faktor internal, hal ini didasarkan pada penelitian menyatakan bahwa terdapat pengaruh yang positif dan signifikan antara faktor internal dengan faktor eksternal terhadap prestasi belajar siswa, dimana yang paling mempengaruhi prestasi belajar siswa adalah faktor internal [21].

Fokus dalam penelitian ini adalah siswa kelas VII SMP Negeri 1 Tempursari, hal ini dikarenakan siswa kelas VII merupakan siswa yang sedang dalam masa peralihan dari kanak-kanak (saat masih di SD) ke masa remaja (di SMP). Dengan demikian, dapat dimengerti bahwa dampak luas dari peralihan masa remaja ini rentan dengan emosi siswa yang labil, sehingga siswa harus berusaha menyesuaikan diri untuk dapat tetap mengikuti pembelajaran matematika walaupun dilaksanakan secara daring. Pembelajaran daring matematika dipilih karena matematika merupakan mata pelajaran yang mayoritas dianggap sulit oleh siswa, bukan hanya siswa yang berkemampuan rendah yang mengalami kesulitan dalam memahami materi matematika, namun siswa yang berkemampuan sedang dan tinggi juga dapat mengalami kesulitan [24]. Berdasarkan paparan diatas, maka tujuan dari penelitian ini yaitu untuk mengetahui hubungan antara kebiasaan belajar dengan prestasi belajar matematika, antara motivasi belajar dengan 
prestasi belajar matematika, serta kebiasaan dan motivasi belajar terhadap prestasi belajar matematika siswa.

\section{METODE PENELITIAN}

Penelitian ini merupakan penelitian kuantitatif yang bertujuan untuk menganalisis hubungan antara kebiasaan belajar dan motivasi belajar dengan prestasi belajar matematika siswa selama pembelajaran daring secara parsial dan simultan. Instrumen yang digunakan dalam penelitian ini adalah angket dan lembar validasi. Lokasi pada penelitian ini adalah SMP Negeri 1 Tempursari. Jumlah populasi adalah 185 siswa kelas VII, dengan teknik pengambilan sampel menggunakan pendekatan rumus Slovin sehingga didapatkan jumlah sampel sebanyak 123 siswa kelas VII SMPN 1 Tempursari yang terdiri dari 21 siswa kelas VII-A, 20 siswa kelas VII-B, 21 siswa kelas VII-C, 20 siswa kelas VII-D, 21 siswa kelas VII-E, dan 20 siswa kelas VII-F.

Sumber data primer pada penelitian ini adalah instrumen angket kebiasaan belajar dan angket motivasi belajar, sedangkan sumber data sekunder pada penelitian ini adalah dokumen SMP Negeri 1 Tempursari berupa nilai prestasi belajar matematika siswa kelas VII selama pembelajaran daring pada semester genap Tahun Ajaran 2020/2021. Skala pengukuran instrumen angket menggunakan skala Likert, dimana untuk pernyataan positif terdapat pilihan selalu (skor 4), sering (skor 3), jarang (skor 2), dan tidak pernah (skor 1); untuk pernyataan negatif terdapat pilihan selalu (skor 1), sering (skor 2), jarang (skor 3), dan tidak pernah (skor 4). Data yang dihasilkan pada pengukuran skala Likert berupa data ordinal, dimana selanjutnya data tersebut perlu ditransformasi ke dalam bentuk data interval dengan menggunakan bantuan software Excel. Transformasi data perlu dilakukan sebagai syarat penggunaan analisis regresi yang mengharuskan data berskala interval.

Instrumen yang digunakan sebelumnya harus melalui tahapan proses validasi oleh validator dan uji butir instrumen yaitu uji validitas dan reliabilitas butir pernyataan pada instrumen. Validasi instrumen dilakukan oleh dua Dosen Program Studi Pendidikan Matematika FKIP Universitas Jember. Berdasarkan perhitungan analisis data hasil validasi angket, diperoleh $V_{\alpha}$ sebesar 3,7. Nilai $V_{\alpha}$ tersebut berada pada $3 \leq V_{\alpha} \leq 4$, berdasarkan pada kriteria kevalidan instrumen, maka instrumen angket dinyatakan valid. Instrumen yang telah divalidasi oleh validator selanjutnya dilakukan uji butir instrumen. Uji butir instrumen pada penelitian ini dilakukan kepada responden selaku siswa Kelas VIII SMPN 1 Tempursari yang diambil sebanyak 60 siswa kelas VIII sebagai responden diluar subjek penelitian.

Hasil pengolahan data dengan menggunakan teknik Pearson Correlation untuk uji validitas butir instrumen dan teknik Chronbach's Alpha untuk uji reliabilitas instrumen dengan bantuan software SPSS versi 24 didapatkan bahwa instrumen angket yang dinyatakan valid dan reliabel adalah 23 butir pernyataan dari 24 butir pernyataan pada angket kebiasaan belajar dan 41 butir pernyataan dari 41 butir pernyataan pada angket motivasi belajar yang telah divalidasi oleh validator.

Uji asumsi klasik pada penelitian ini adalah uji normalitas, uji heteroskedastisitas dan uji multikolinearitas. Analisis yang digunakan adalah analisis regresi linier berganda, uji Korelasi Pearson, uji F, dan uji determinasi.

\section{HASIL DAN PEMBAHASAN}

Uji asumsi klasik yang digunakan dalam penelitian ini adalah uji normalitas, uji heteroskedastisitas dan uji multikolinearitas, hasil dari uji asumsi klasik terdapat pada 
tabel 1.

Tabel 1. Hasil Uji Asumsi Klasik

\begin{tabular}{llll}
\hline Uji Asumsi Klasik & $\begin{array}{l}\text { Uji yang } \\
\text { digunakan }\end{array}$ & Hasil & Keterangan \\
\hline Uji Normalitas & $\begin{array}{l}\text { Kolmogorov- } \\
\text { Smirnov }\end{array}$ & $\begin{array}{l}\text { Nilai Sig. Residual }= \\
0.092\end{array}$ & $\begin{array}{l}\text { Data berdistribusi } \\
\text { normal }\end{array}$ \\
\hline Uji & Nilai Sig. Kebiasaan & Telajar $=0.689$ \\
Heteroskedastisitas & Uji Glejser & $\begin{array}{l}\text { Nilai Sig. Motivasi } \\
\text { Belajar }=0.176\end{array}$ & $\begin{array}{l}\text { Tidak terjadi gejala } \\
\text { heteroskedastisitas }\end{array}$ \\
\hline $\begin{array}{l}\text { Uji } \\
\text { Multikolinearitas }\end{array}$ & Tolerance dan VIF & $\begin{array}{l}\text { Nilai Tolerance }=0.511 \\
\text { Nilai VIF }=1.957\end{array}$ & $\begin{array}{l}\text { Tidak terjadi gejala } \\
\text { multikolinearitas }\end{array}$ \\
\hline
\end{tabular}

Berdasarkan hasil uji normalitas, didapatkan nilai Sig. residual lebih dari 0.05, artinya data pada penelitian ini memiliki nilai residual yang berdistribusi normal dan uji regresi dapat digunakan. Berdasarkan uji heteroskedastisitas, didapatkan nilai signifikansi dari variabel kebiasaan belajar dan motivasi belajar secara berurutan adalah sebesar 0.689 dan 0.176 , dimana kedua nilai signifikansi tersebut lebih dari 0.05 , maka antar regresi pada regresi pada variabel bebas terhadap nilai absolut residual tidak terjadi gejala heteroskedastisitas dan uji regresi dapat digunakan. Berdasarkan uji multikolinearitas, didapatkan nilai tolerance sebesar 0.511 lebih besar dari 1.0 dan nilai VIF sebesar 1.957 kurang dari 10, maka variabel bebas kebiasaan belajar dan motivasi belajar terhadap prestasi belajar matematika tidak terjadi gejala multikolinearitas dan selanjutnya dapat dilakukan uji regresi untuk menguji hipotesis.

\section{A. Analisis Regresi Linier Berganda}

Tabel 2. Hasil Koefisien Regresi Linier Berganda

\begin{tabular}{cc}
\hline Model & Nilai Koefisien \\
\hline Konstanta & 19.912 \\
\hline $\boldsymbol{X}_{\mathbf{1}}$ (Kebiasaan Belajar) & 0.371 \\
\hline $\boldsymbol{X}_{\mathbf{2}}$ (Motivasi Belajar) & 0.503 \\
\hline
\end{tabular}

Pada tabel 2, dari kolom nilai koefisien diperoleh persamaan regresi sebagai berikut: $\quad Y=19.912+0.371 X_{1}+0.503 X_{2}$. Pada persamaan tersebut dapat diinterpretasikan sebagai berikut:

1) Nilai konstanta sebesar 19.912, memiliki arti apabila nilai dari variabel bebas $X_{1}$ dan $X_{2}$ bernilai nol, maka nilai dari variabel terikat Y adalah sebesar 19.912.

2) Nilai koefisien variabel kebiasaan belajar $\left(X_{1}\right)$ sebesar 0.371 , memiliki arti apabila untuk setiap kenaikan kebiasaan belajar sebesar satu satuan maka variabel prestasi belajar matematika (Y) mengalami kenaikan sebesar 0.371 . Nilai koefisien yang bertanda positif artinya terjadi hubungan positif antara kebiasaan belajar dengan prestasi belajar matematika, dimana semakin naik kebiasaan belajar, maka semakin naik prestasi belajar matematika siswa.

3) Nilai koefisien variabel motivasi belajar $\left(X_{2}\right)$ sebesar 0.503 , memiliki arti apabila untuk setiap kenaikan motivasi belajar sebesar satu satuan maka variabel prestasi belajar matematika (Y) mengalami kenaikan sebesar 0.503 . Berdasarkan hal tersebut, maka nilai koefisien variabel motivasi belajar dapat dikatakan signifikan. Nilai koefisien yang bertanda positif artinya terjadi hubungan positif antara motivasi belajar dengan prestasi belajar matematika, 
dimana semakin naik motivasi belajar, maka semakin naik prestasi belajar matematika siswa.

\section{B. Uji Korelasi Pearson}

Pada penelitian ini, untuk mengetahui hubungan setiap variabel bebas terhadap variabel terikat digunakan Korelasi Pearson. Taraf signifikan yang digunakan pada penelitian ini adalah 5\%. Hasil uji Korelasi Pearson terdapat pada tabel 5

Tabel 3. Hasil Uji Korelasi Pearson

\begin{tabular}{ccc}
\hline Variabel & Nilai Sig. & Nilai Pearson Correlation \\
\hline Kebiasaan Belajar $\left(\boldsymbol{X}_{\mathbf{1}}\right)$ & 0.000 & $(+) 0.495$ \\
\hline Motivasi Belajar $\left(\boldsymbol{X}_{\mathbf{2}}\right)$ & 0.000 & $(+) 0.523$ \\
\hline
\end{tabular}

Pada tabel 3, diketahui bahwa variabel kebiasaan belajar $\left(X_{1}\right)$ memiliki nilai signifikansi (Sig.) sebesar 0.000. Berdasarkan kriteria pengambilan keputusan untuk uji Korelasi Pearson, diperoleh bahwa nilai Sig. sebesar $0.000<0.05$, maka hipotesis Ho ditolak dan $\mathrm{Ha}_{1}$ diterima, artinya terdapat hubungan antara kebiasaan belajar terhadap prestasi belajar matematika siswa kelas VII SMP Negeri 1 Tempursari selama pembelajaran daring semester genap Tahun Ajaran 2020/2021. Nilai Pearson Correlation untuk kebiasaan belajara sebesar (+) 0.495 . Tanda positif tersebut menunjukkan bahwa hubungan kebiasaan belajar dengan pretasi belajar matematika siswa mempunyai korelasi positif. Nilai 0.495 menginterpretasikan bahwa kebiasaan belajar dengan prestasi belajar matematika siswa mempunyai korelasi yang sedang karena berada pada interval $0.26-0.50$.

Untuk variabel motivasi belajar $\left(X_{2}\right)$ pada tabel 5, memiliki nilai signifikansi (Sig.) sebesar 0.000. Berdasarkan kriteria pengambilan keputusan untuk uji Korelasi Pearson, diperoleh bahwa nilai Sig. sebesar $0.000<0.05$, maka hipotesis $\mathrm{Ho}_{2}$ ditolak dan $\mathrm{Ha}_{2}$ diterima, artinya terdapat hubungan antara motivasi belajar terhadap prestasi belajar matematika siswa kelas VII SMP Negeri 1 Tempursari selama pembelajaran daring semester genap Tahun Ajaran 2020/2021. Nilai Pearson Correlation untuk kebiasaan belajara sebesar (+) 0.523. Tanda positif tersebut menunjukkan bahwa hubungan motivasi belajar dengan pretasi belajar matematika siswa mempunyai korelasi positif. Nilai 0.523 menginterpretasikan bahwa kebiasaan belajar dengan prestasi belajar matematika siswa mempunyai korelasi yang kuat karena berada pada interval $0.51-0.75$.

\section{Uji F}

Pada penelitian ini, untuk mengetahui hubungan variabel bebas secara simultan terhadap variabel terikat digunakan uji F. Taraf signifikan yang digunakan adalah $5 \%$. Berdasarkan hasil penelitian, diperoleh nilai signifikansi (Sig.) sebesar 0.000 dan nilai $\mathrm{R}$ sebesar 0.554. Berdasarkan kriteria pengambilan keputusan untuk uji F, diperoleh bahwa nilai Sig. sebesar $0.000<0.05$, maka hipotesis $\mathrm{Ho}_{3}$ ditolak dan $\mathrm{Ha}_{3}$ diterima, artinya terdapat hubungan antara kebiasaan belajar dan motivasi belajar dengan prestasi belajar matematika siswa kelas VII SMPN 1 Tempursari selama pembelajaran daring semester genap Tahun Ajaran 2020/2021. Nilai Pearson Correlation (nilai R) untuk kebiasaan belajar dan motivasi belajar sebesar $(+) 0.554$. Tanda positif tersebut menunjukkan bahwa hubungan kebiasaan belajar dan motivasi belajar dengan prestasi belajar matematika siswa mempunyai korelasi positif. Nilai 0.554 menginterpretasikan bahwa 
antara kebiasaan belajar dan motivasi belajar dengan prestasi belajar matematika siswa mempunyai korelasi yang kuat karena berada pada interval $0.51-0.75$.

\section{Koefisien Determinasi}

Pada penelitian ini, untuk mengetahui besarnya pengaruh yang diberikan variabel bebas $\left(X_{1}\right.$ dan $\left.X_{2}\right)$ secara simultan terhadap variabel terikat $(Y)$ dapat dilihat pada nilai koefisien determinasi $\left(R^{2}\right)$ hasil dari regresi. Besarnya koefisien determinasi berada antara nol dan satu $(0<R 2<1)$ dan dapat dinyatakan dalam bentuk persentase. Hasil koefisien determinasi ( $R$ Square) untuk variabel kebisaan belajar dan motivasi belajar $\left(X_{1}\right.$ dan $\left.X_{2}\right)$ sebesar 0.307 atau $30.7 \%$, artinya pengaruh dari variabel kebiasaan belajar dan motivasi belajar secara simultan terhadap prestasi belajar matematika siswa adalah sebesar $30.7 \%$, sedangkan $60.3 \%$ dipengaruhi oleh variabel bebas lain yang tidak diteliti dalam penelitian ini.

Pada penelitian ini, analisis data dilakukan dengan menggunakan bantuan software SPSS Versi 24. Hasil uji asumsi klasik yang terdiri dari uji normalitas, uji heteroskedastisitas, dan uji multikolinearitas menunjukkan bahwa persamaan regresi yang telah didapatkan dapat digunakan untuk mengetahui pengaruh dari variabel bebas kebiasaan belajar dan motivasi belajar terhadap variabel terikat prestasi belajar matematika. Berdasarkan hasil uji normalitas, didapatkan nilai Sig. residual lebih dari 0.05 , artinya data pada penelitian ini memiliki nilai residual yang berdistribusi normal dan uji regresi dapat digunakan. Berdasarkan uji heteroskedastisitas, didapatkan nilai signifikansi dari variabel kebiasaan belajar dan motivasi belajar secara berurutan adalah sebesar 0.689 dan 0.176, dimana kedua nilai signifikansi tersebut lebih dari 0.05 , maka antar regresi pada regresi pada variabel bebas terhadap nilai absolut residual tidak terjadi gejala heteroskedastisitas dan uji regresi dapat digunakan. Berdasarkan uji multikolinearitas, didapatkan nilai tolerance sebesar 0.511 lebih besar dari 1.0 dan nilai VIF sebesar 1.957 kurang dari 10, maka variabel bebas kebiasaan belajar dan motivasi belajar terhadap prestasi belajar matematika tidak terjadi gejala multikolinearitas dan uji regresi dapat digunakan.

Hasil analisis untuk variabresel kebiasaan belajar, menunjukkan bahwa terdapat hubungan positif dan signifikan antara kebiasaan belajar dengan prestasi belajar matematika siswa kelas VII SMP Negeri 1 Tempursari selama pembelajaran daring semester genap Tahun Ajaran 2020/2021. Hal ini dibuktikan dengan hasil uji Korelasi Pearson sebesar (+) 0.495 dan nilai Sig. $0.000<0.05$, maka hasil pengujian untuk hipotesis pertama $H_{1}$ ditolak dan $H \alpha_{1}$ diterima, artinya terdapat hubungan antara kebiasaan belajar terhadap prestasi belajar matematika siswa.

Hasil penelitian ini memiliki hubungan positif dan signifikan antara kebiasaan belajar dengan prestasi belajar matematika siswa, dimana hubungan antara keduanya memiliki hubungan yang sedang (0.495). Hal ini sejalan dengan pendapat yang menyatakan bahwa siswa dapat mengembangkan sikap, kebiasaan dan tingkah laku yang baik dalam belajarnya agar dapat mencapai prestasi belajar yang optimal [22]. Berdasarkan hal tersebut maka kebiasaan belajar memiliki hubungan dengan prestasi belajar siswa. Hasil penelitian ini sejalan dengan penelitian yang mengemukakan bahwa kebiasaan belajar berkorelasi positif dengan prestasi belajar yaitu sebesar 0.6477 (kuat) [15]. Adanya perbedaan hubungan yang ditimbulkan dalam penelitian ini dimana terjadi penurunan hubungan, dari hubungan yang kuat menjadi hubungan yang sedang.

Terdapat perubahan pada kebiasaan belajar siswa dikarenakan pembelajaran dilaksanakan secara daring, sehingga hubungan keduanya memiliki penurunan. Hal ini sejalan dengan pendapat yang menyatakan bahwa dalam kegiatan belajarnya, siswa 
mengalami kejenuhan selama belajar dalam situasi pandemi, serta timbulnya perasaan bosan pada siswa ketika mengerjakan tugas - tugas sekolah yang diberikan guru [10]. Berdasarkan pendapat tersebut, peneliti menggali informasi kepada siswa mengenai perubahan kebiasaan belajar siswa selama masa normal dengan masa pandemi, dimana dalam mengerjakan tugas yang diberikan, apabila selama masa normal tugas dapat diselesaikan di awal waktu, namun karena pembelajaran daring selama masa pandemi, dalam mengerjakan tugas yang diberikan terkadang ditunda - tunda sampai akhinya tugas menumpuk.

Hasil analisis untuk variabel motivasi belajar, menunjukkan bahwa terdapat hubungan positif dan signifikan antara motivasi belajar dengan prestasi belajar matematika siswa kelas VII SMP Negeri 1 Tempursari selama pembelajaran daring semester genap Tahun Ajaran 2020/2021. Hal ini dibuktikan dengan hasil uji Korelasi Pearson sebesar (+) 0.523 dan nilai Sig. $0.000<0.05$, maka hasil pengujian untuk hipotesis kedua $\mathrm{Ho}_{2}$ ditolak dan $\mathrm{Ha}_{2}$ diterima, artinya terdapat hubungan antara motivasi belajar terhadap prestasi belajar matematika siswa.

Hasil penelitian ini memiliki hubungan positif dan signifikan antara kebiasaan belajar dengan prestasi belajar matematika siswa, dimana hubungan antara keduanya memiliki hubungan yang kuat (0.523). Hal ini sejalan dengan pendapat yang mengemukakan bahwa semakin kuat motivasi belajar dari siswa maka semakin kuat pula upayanya untuk berpastisipasi dalam belajar, dimana partisipasi belajar atau kinerja yang dilakukan siswa ini memiliki korelasi yang kuat dengan prestasi belajar siswa [23]. Berdasarkan hal tersebut, motivasi belajar siswa berkorelasi dengan partisipasi belajar, sedangkan partisipasi belajar berkorelasi dengan prestasi belajar, maka dapat dikatakan bahwa motivasi belajar siswa berkorelasi kuat dengan prestasi belajar siswa. Hasil penelitian ini sejalan dengan penelitian yang menyatakan bahwa motivasi belajar berkorelasi positif dengan prestasi belajar yaitu sebesar 0.6113 (kuat) [15]. Penelitian lain yang sejalan dengan penelitian ini yaitu penelitian dengan hasil bahwa motivasi belajar berkorelasi positif dengan prestasi belajar matematika siswa yaitu sebesar 0.53 (kuat) [14]. Berdasarkan hasil penelitian tersebut, terjadi penurunan apabila dilihat dari besaran korelasi pada penelitian ini yaitu 0.523 (kuat).

Adanya perbedaan besaran korelasi ini disebabkan karena pembelajaran dilaksanakan secara daring. Hal ini sejalan dengan pendapat yang mengemukakan bahwa akibat dari pembelajaran yang dilaksanakan secara online menyebabkan penurunan motivasi yang disebabkan karena siswa yang belum beradaptasi untuk belajar secara daring [12]. Berdasarkan pendapat tersebut, peneliti menggali informasi pada siswa mengenai perubahan motivasi siswa selama mengikuti pembelajaran normal dengan pembelajaran daring, dimana pada masa normal guru menjelaskan secara langsung materi yang akan diajarkan kepada siswa namun selama mengikuti pembelajaran daring siswa merasa kurang bisa memahami materi yang diberikan guru. Guru mengirimkan link video pembelajaran, namun banyak siswa yang tidak dapat mengakses video tersebut karena lingkungan tempat tinggal siswa yang susah dijangkau sinyal untuk mengakses video tersebut, selain itu proses pemahaman siswa setiap siswa berbeda - beda dimana tidak semua siswa dapat memahami hanya dengan video pembelajaran tersebut.

Hasil analisis untuk variabel kebiasaan belajar dan motivasi belajar secara bersama - sama, menunjukkan bahwa terdapat hubungan positif dan signifikan antara kebiasaan belajar dan motivasi belajar dengan prestasi belajar matematika siswa kelas VII SMP Negeri 1 Tempursari selama pembelajaran daring semester genap Tahun Ajaran 2020/2021. Hal ini dibuktikan dengan hasil uji Korelasi Pearson sebesar (+) 0.554 dan nilai Sig. $0.000<0.05$, maka hasil pengujian untuk hipotesis ketiga $\mathrm{Ho}_{3}$ ditolak dan $\mathrm{H \alpha}_{3}$ 
diterima, artinya terdapat hubungan antara kebiasaan belajar dan motivasi belajar terhadap prestasi belajar matematika siswa.

Hasil penelitian ini memiliki hubungan positif dan signifikan antara kebiasaan belajar dan motivasi belajar dengan prestasi belajar matematika siswa, dimana hubungannya memiliki hubungan yang kuat (0.554). Kebiasaan belajar siswa merupakan aktivitas atau kegiatan belajar yang dilakukan siswa secara berulang sehingga memunculkan suatu kebiasaan belajar siswa diluar jam pembelajaran daring, sedangkan motivasi belajar siswa akan mendorong siswa untuk berupaya mewujudkan impiannya, dimana dalam hal ini merupakan prestasi belajar matematika siswa di masa pembelajaran daring, dimana upaya - upaya tersebut dapat nampak dari perilaku, perasaan, dan kondisi siswa selama mengikuti pembelajaran daring. Hal ini menunjukkan bahwa kebiasaan belajar siswa yang kurang baik disertai dengan motivasi belajar siswa yang kurang maka akan berdampak negatif terhadap prestasi belajar siswa. Kedua faktor ini yaitu kebiasaan belajar dan motivasi belajar harus benar - benar diperhatikan karena berhubungan dengan prestasi belajar siswa.

Berdasarkan hasil pengujian determinasi, kontribusi variabel kebiasaan belajar dan motivasi belajar secara bersama - sama terhadap prestasi belajar matematika sebesar 0.307 artinya kebiasaan belajar dan motivasi belajar memberikan kontribusi pengaruh secara simultan sebesar $30.7 \%$ terhadap prestasi belajar matematika siswa, sedangkan $60.3 \%$ dipengaruhi oleh faktor lain yang tidak diteliti dalam penelitian ini. Faktor lain yang tidak diteliti dalam penelitian ini dapat berupa faktor lain yang mempengaruhi prestasi belajar siswa yaitu kemampuan, minat dan perhatian, sikap, ketekunakan, faktor fisik dan psikis, serta lingkungan.

Hasil penelitian ini sejalan dengan hasil penelitian yang pernah dilakukan dengan hasil dimana motivasi belajar dan kebiasaan belajar berpengaruh secara simultan terhadap prestasi belajar ekonomi siswa kelas XI IPS SMAN 14 Medan Tahun Ajaran 2016/2017 [14]; tetapi berbeda besar pengaruhnya sebesar $88.5 \%$ dan sisanya yaitu sebesar $11.5 \%$ dipengaruhi oleh variabel bebas lain yang tidak diteliti oleh peneliti. Penelitian lain yang mendukung hasil penelitian ini yaitu hasil penelitian yang pernah dilakukan, dengan hasil dimana kebiasaan belajar dan motivasi belajar berpengaruh secara parsial dan simultan terhadap prestasi belajar siswa pada mata pelajaran seni budaya, dengan pengaruh secara simultan sebesar $65.4 \%$ dan sisanya yaitu 34.6\% dipengaruhi oleh variabel bebas lain diluar penelitian [20]. Perbedaan besaran pengaruh yang diberikan disebabkan pada pelaksanaan penelitian tersebut yang dilaksanakan pada masa normal, sedangkan pada penelitian ini dilaksanakan pada masa pandemi Covid-19.

\section{KESIMPULAN}

Berdasarkan analisis hubungan kebiasaan antara belajar dan motivasi belajar dengan prestasi belajar matematika siswa kelas VII SMP Negeri 1 Tempursari selama pembelajaran daring semester genap Tahun Ajaran 2020/202, maka dapat disimpulkan sebagai berikut: terdapat hubungan positif dan signifikan antara kebiasaan belajar dengan prestasi belajar matematika siswa kelas VII SMP Negeri 1 Tempursari selama pembelajaran daring semester genap Tahun Ajaran 2020/2021, dimana hubungan keduanya berkorelasi sedang; terdapat hubungan positif dan signifikan antara motivasi belajar dengan prestasi belajar matematika siswa kelas VII SMP Negeri 1 Tempursari selama pembelajaran daring semester genap Tahun Ajaran 2020/2021, dimana hubungan keduanya berkorelasi kuat; terdapat hubungan positif dan signifikan antara kebiasaan belajar dan motivasi belajar dengan prestasi belajar matematika siswa kelas VII SMP Negeri 1 Tempursari selama pembelajaran daring semester genap Tahun Ajaran 
2020/2021, dimana hubungan ganda ketiganya berkorelasi kuat. Kebiasaan belajar dan motivasi belajar memberikan kontribusi pengaruh secara simultan sebesar $30.7 \%$ terhadap prestasi belajar matematika siswa, sedangkan $60.3 \%$ dipengaruhi oleh faktor lain yang tidak diteliti dalam penelitian ini. Faktor lain yang tidak diteliti dalam penelitian ini dapat berupa faktor lain yang mempengaruhi prestasi belajar siswa yaitu kemampuan, minat dan perhatian, sikap, ketekunakan, faktor fisik dan psikis, serta lingkungan. Rendahnya pengaruh yang diberikan dapat terjadi karena pada penelitian ini dilakukan pada masa pandemi, sehingga besaran pengaruh tidak sebesar saat penelitian dilakukan pada masa normal. Berdasarkan hasil penelitian dan kesimpulan, peneliti berharap agar peneliti selanjutnya dapat mengembangkan variabel-variabel lain yang dapat mempengaruhi prestasi belajar matematika siswa selama masa pembelajaran daring, dikarenakan pengaruh yang diberikan pada penelitian ini hanya $30,7 \%$, sedangkan $60,3 \%$ dipengaruhi oleh banyak faktor lain yang dapat diteliti oleh peneliti selanjutnya, atau dapat pula dengan membandingkan hubungan kebiasaan belajar dan motivasi belajar dengan prestasi belajar dimana pada penelitiannya membandingkan pelaksanaan pembelajaran daring dengan luring.

\section{DAFTAR PUSTAKA}

[1] M. Chryshna. (2020). Kebijakan Pendidikan Formal Anak pada Masa Pandemi Covid-19.

[2] Sadikin, A., dan A. Hamidah. (2020). Pembelajaran Daring di Tengah Wabah Covid-19. Jurnal Ilmiah Pendidikan Biologi. 6(02): 214-224.

[3] Neolaka, A., dan G, Amialia. (2017). Landasan Pendidikan Dasar Pengenalan Diri Sendiri Menuju Perubahan Hidup. Depok: PT. Kharisma Putra Utama.

[4] Sanjaya, R. (2020). Gamifikasi Pembelajaran Daring.

[5] Monalisa, Lioni A., dan D. Trapsilasiwi. (2015). Penerapan Model Pembelajaran Kooperatif Tipe Jigsaw Pada Pokok Bahasan Keterbagian Bilangan Bulat Untuk Meningkatkan Aktivitas Mahasiswa Semester VI Tahun Ajaran 2014-2015 Program Studi Pendidikan Matematika Fakultas Keguruan dan Ilmu Pendidikan Universitas Jember. Pancaran. 4(2): 173 - 180.

[6] Pambudi, Didik S. (2007). Berbagai Alternatif Model dan Pendekatan dalam Pembelajaran Matematika. Jurnal Pendidikan Matematika. 1(2): 39-45.

[7] Hawadi, R. A. (2004). Akselerasi A-Z Informasi Program Percepatan Belajar dan Anak Berbakat Intelektual. Jakarta: Gramedia Widiasarana Indonesia.

[8] Susanto, Ahmad. (2013). Teori Belajar dan Pembelajaran di Sekolah Dasar. Jakarta: Prenadamedia Grup

[9] Pohan, A. E. (2020). Konsep Pembelajaran Daring Berbasis Pendekatan Ilmiah. Grobogan: CV. Sarnu Untung

[10] Wijoyo, Hadion. (2021). Efektivitas Proses Pembelajaran di Masa Pandemi. Sumatera Barat: CV Insan Cendekia Mandiri.

[11] Susana, T. (2006). PR dan Pelajaran Sulit Bisa Menyenangkan. Yogyakarta: KANISIUS

[12] Setyami, Inung. (2021). Bunga Rampai: Membaca Corona Membaca Realita. Yogyakarta: Jejak Pustaka.

[13] Lestari, E. T. (2020). Cara Praktis Meningkatkan Motivasi Siswa Sekolah Dasar. Yogyakarta: DEEPUBLISH.

[14] Jemudin, Frederik D.E., Alberta P. M., dan Ferdinandus A. A. (2019). Hubungan Sikap Belajar dan Motivasi Belajar terhadap Prestasi Belajar Matematika Siswa 
SMPN 6 Langke Rembong. Journal of Honai Math. 2 (1): 1-11.

[15] Lase, Sadiana. (2018). Hubungan antara Motivasi dan Kebiasaan Belajar terhadap Prestasi Belajar Matematika Siswa SMP. Jurnal Warta Edisi 56.

[16] Soleha. (2018). Hubungan Antara Sikap dengan Prestasi Belajar Matematika Siswa Kelas V SD Negeri Dipawangi. Jurnal PRISMA Universitas Suryakancana.

[17] Laksono, Yustinus S., Gregoria, A., dan Fransiskus, G. I. S. (2013). Hubungan Minat Belajar Siswa terhadap Prestasi Belajar Matematika Siswa dalam Pembelajaran Kooperatif Tipe STAD Menggunakan Komik. Jurnal Edukasi Matematika dan Sains. 1(2): 60-64.

[18] Kartika, Mutiara A. (2020). Hubungan antara Gaya Belajar dengan Prestasi Belajar Siswa (Studi Kasus Prestasi Belajar Siswa di MAN 2 Palembang). Skripsi. Universitas Islam Negeri Raden Fatah: Palembang.

[19] Lubis, S. Y. (2017). Pengaruh Motivasi Belajar dan Kebiasaan Belajar Siswa Terhadap Prestasi Belajar Ekonomi Siswa Kelas XI IPS SMA Negeri 14 Medan Tahun Ajaran 2016/2017. Skripsi. Medan: Universitas Medan.

[20] Afif, R. T. (2013). Pengaruh Kebiasaan Belajar dan Motivasi Belajar terhadap Prestasi Belajar Siswa pada Mata Pelajaran Seni Budaya. Skripsi. Bandung: Universitas Pendidikan Indonesia.

[21] Varera, Linna. (2018). Pengaruh Faktor Internal dan Eksternal Siswa terhadap Prestasi Belajar pada Mata Pelajaran Pengetahuan Bahan Tekstil Kelas X Busana SMK Islam Moyudan. Skripsi. Yogyakarta: Universitas Negeri Yogyakarta.

[22] Dayana, Indri., dan Marbun, Juliaster. (2019). Tips dan Trik Membimbing Olimpiade dan Riset untuk Tingkat SMA dan Perguruan Tinggi. Guepedia Publisher.

[23] Gintings, Abdorrakhman. (2012). Esensi Praktis Belajar dan Pembelajaran: Disiapkan untuk Pendidikan dan Sertifikasi Guru-Dosen Edisi Revisi. Bandung: Humaniora Utama Press.

[24] Limardani, G., D. Trapsilasiwi., dan A. Fatahillah. (2015). Analisis Kesulitan Siswa dalam Menyelesaikan Soal Operasi Aljabar Berdasarkan Teori Pemahaman Skemp pada Siswa Kelas VIII D SMP Negeri 4 Jember. Artikel Ilmiah Mahasiswa. 1 (1): $1-7$. 